A C G

publications

Rec. Nat. Prod. 12:5 (2018) 426-431

records of natural products

\title{
Composition of the Essential Oil of Salvia montbretii Benth. from Turkey
}

\author{
Fatma Abak $\odot^{1}$, Gulsum Yildiz $\odot^{2}$, Vagif Atamov $\odot^{1}$ and Mine Kurkcuoglu $\odot^{2^{*}}$ \\ ${ }^{I}$ Recep Tayyip Erdoğan Unıversity, , Faculty of Science and Literature, Department of Biology, \\ Rize, Türkiye \\ ${ }^{2}$ Anadolu University, Faculty of Pharmacy, Department of Pharmacognosy, 26470, Eskisehir, Türkiye
}

(Received December 27, 2017; Revised January 28, 2018; Accepted January 30, 2018)

\begin{abstract}
The composition of the essential oil produced from aerial parts of Salvia montbretii Benth.(Lamiaceae), was analyzed by GC and GC-MS. Forty-six compounds constituting about $97.7 \%$ of the essential oil were characterized.The main compounds were characterized as $\beta$-caryophyllene (32.8\%), $\beta$-pinene (9.8\%), $\alpha$-humulene (8.2\%), 12-hydroxy- $\beta$-caryophyllene acetate (6.6\%), germacrene D (4.9\%) and $\alpha$-pinene $(4.5 \%)$.
\end{abstract}

Keywords: Salvia montbretii Benth; oil composition; $\beta$-caryophyllene; $\alpha$-humulene; $\beta$-pinene. (C) 2018 ACG Publications. All rights reserved.

\section{Introduction}

Salvia L. is one of the largest genera in the family Lamiaceae with 900 species in the World. Salvia genus is represented by 100 species, 53\% of whic are endemic in Turkey [1-3]. Salvia montbretii is named " kara salba" in South-East Anatolia, Turkey.

Numerous Salvia species are used both internally and externally as folk medicines all around the World. There are several reports on the medicinal uses of some species of the genus, mainly against cold, skin infections, wounds, pharyngitis, stomatitis, stomachache, headache, memory enhancement and galactorrhoea [4].

The chemical compositions of several Salvia species have been extensively investigated revealing the presence of terpenes, triterpenoids, diterpenoids, tannins, phenolics and essential oil [3$18]$.

Previous phytochemical studies on Salvia montbretii Benth. have reported the presence of abiatane diterpenes and triterpenoids. Salvibretol, 1-oxosalvibretol, 6-hydroxysalvinolone, 7hydroxytaxodione, 7,7'-bistaxodione, and 11,'-didehydroxy-7,7'-dihydroxytaxodione, montbretol, montbretyl 12-methyl ester, 14-hydroxy ferruginol, 3- $\beta$-O-cis-p-coumaroylmonogynol and 3- $\beta-\mathrm{O}-$ trans-p-coumaroylmonogynol were isolated from root of $S$. montbretii [15-17].

\footnotetext{
* Corresponding author: E-Mail: minekurkcuoglu@gmail.com Phone:+90 2223350580
} 
In previous study, water-distilled essential oil of S. montbretii was analyzed using GC and GCMS and thymol (24.0\%) and caryophyllene oxide (26.9\%) were found to be the main components in the oil [19].

\section{Materials and Methods}

\subsection{The Plant Material}

Salvia montbretii was collected from Şanlıurfa: between Çatak -Bozova in Turkey on 20 May 2017. The voucher specimenhas been deposited at the Herbarium in the Recep Tayyip Erdoğan University (RTEUB 6079), Rize, Turkey (Voucher specimen no: FABAK 1478). The plant material was identified by Prof. Dr. Vagif ATAMOV (Recep Tayyip Erdoğan University, Faculty of Science and Literature, Department of Biology, Rize, Turkey).

\subsection{Isolation of the Essential Oil}

Aerial parts of the plant were water distilled for $3 \mathrm{~h}$ using a Clevenger-type apparatus. The essential oil was stored at $4{ }^{\circ} \mathrm{C}$ in the dark until analyzed. Oil yield in the sample was less than $0.1 \%$.

\subsection{Gas Chromatography (GC) and Gas Chromatography -Mass Spectrometry (GC-MS) Analysis}

The oil was analyzed by Gas Chromatography (GC) and Gas Chromatography-Mass Spectrometry (GC-MS) using a Agilent GC-MSD system (Mass Selective Dedector-MSD).

\subsubsection{GC-MS Analysis}

The GC-MS analysis was carried out with an Agilent 5975 GC-MSD system (Agilent, USA; SEM Ltd., Istanbul, Turkey). Innowax FSC column $(60 \mathrm{~m} \times 0.25 \mathrm{~mm}, 0.25 \mu \mathrm{m}$ film thickness) was used with helium as carrier gas $(0.8 \mathrm{~mL} / \mathrm{min})$. GC oven temperature was kept at $60^{\circ} \mathrm{C}$ for $10 \mathrm{~min}$ and programmed to $220^{\circ} \mathrm{C}$ at a rate of $4^{\circ} \mathrm{C} / \mathrm{min}$, and kept constant at $220^{\circ} \mathrm{C}$ for $10 \mathrm{~min}$ and then programmed to $240^{\circ} \mathrm{C}$ at a rate of $1{ }^{\circ} \mathrm{C} / \mathrm{min}$. Split ratio was adjusted $40: 1$. The injector temperature was at $250^{\circ} \mathrm{C}$. The interphase temperature was at $280^{\circ} \mathrm{C}$. MS were taken at $70 \mathrm{eV}$. Mass range was from $\mathrm{m} / \mathrm{z} 35$ to 450 .

\subsubsection{GC Analysis}

GC analyses were performed using an Agilent 6890N GC system. FID temperature was set to $300^{\circ} \mathrm{C}$ and the same operational conditions were applied to a triplicate of the same column used in GC-MS analyses. Simultaneous auto injection was done to obtain equivalent retention times. Relative percentages of the separated compounds were calculated from integration of the peak areas in the GCFID chromatograms.

\subsection{Identification of Compounds}

The components of essential oils were identified by comparison of their mass spectra with those in the Baser Library of Essential Oil Constituents, Adams Library, MassFinder Library, Wiley GC/MS Library [20-22] and confirmed by comparison of their retention indices. These identifications were accomplished by comparison of retention times with authentic samples or by comparison of their relative retention index (RRI) to a series of $n$-alkanes. Alkanes were used as reference points in the calculation of relative retention indices (RRI) [23]. Relative percentage amounts of the separated compounds were calculated from FID chromatograms. The analysis results are expressed as mean percentage \pm standard deviation (SD) $(n=3)$ as listed in Table 1 . 


\section{Results and Discussion}

Essential oil of of Salvia montbretii was hydrodistilled from aerial parts for $3 \mathrm{~h}$ using a Clevenger apparatus and analysed by gas chromatography (GC), and gas chromatography-mass spectrometry (GC-MS).

Table 1. Composition of the essential oil of Salvia montbretii Benth.

\begin{tabular}{|c|c|c|c|c|}
\hline RRI $^{\mathbf{a}}$ & $\mathbf{R R I}^{\mathbf{b}}$ & Compounds & $\%$ & ID \\
\hline $1025^{\mathrm{c}}$ & 1032 & $\alpha$-Pinene & $4.5 \pm 0.1$ & $\mathrm{t}_{\mathrm{R}}, \mathrm{Ms}$ \\
\hline $1117^{\mathrm{c}}$ & 1118 & $\beta$-Pinene & $9.8 \pm 0.3$ & $\mathrm{t}_{\mathrm{R}}, \mathrm{Ms}$ \\
\hline $1122^{\mathrm{c}}$ & 1132 & Sabinene & $1.6 \pm 0.2$ & $\mathrm{t}_{\mathrm{R}}, \mathrm{Ms}$ \\
\hline $1160^{c}$ & 1174 & Myrcene & $1.4 \pm 0.0$ & $\mathrm{t}_{\mathrm{R}}, \mathrm{Ms}$ \\
\hline $1212^{\mathrm{c}}$ & 1203 & Limonene & $2.7 \pm 0.1$ & $\mathrm{t}_{\mathrm{R}}, \mathrm{Ms}$ \\
\hline $1213^{c}$ & 1213 & 1,8-Cineole & $1.4 \pm 0.1$ & $\mathrm{t}_{\mathrm{R}}, \mathrm{Ms}$ \\
\hline $1232^{c}$ & 1246 & $(Z)$ - $\beta$-Ocimene & $0.2 \pm 0.0$ & $\mathrm{t}_{\mathrm{R}}, \mathrm{Ms}$ \\
\hline $1245^{\mathrm{c}}$ & 1255 & $\gamma$-Terpinene & $2.9 \pm 0.1$ & $\mathrm{t}_{\mathrm{R}}, \mathrm{Ms}$ \\
\hline $1249^{d}$ & 1266 & (E)- $\beta$-Ocimene & $0.5 \pm 0.1$ & $\mathrm{t}_{\mathrm{R}}, \mathrm{Ms}$ \\
\hline $1282^{c}$ & 1280 & $p$-Cymene & $0.5 \pm 0.1$ & $\mathrm{t}_{\mathrm{R}}, \mathrm{Ms}$ \\
\hline $1282^{\mathrm{c}}$ & 1290 & Terpinolene & $0.2 \pm 0.0$ & $\mathrm{t}_{\mathrm{R}}, \mathrm{Ms}$ \\
\hline $1391^{\mathrm{d}}$ & 1400 & Nonanal & $0.2 \pm 0.0$ & Ms \\
\hline $1399^{\mathrm{d}}$ & 1406 & $\alpha$-Fenchone & $0.2 \pm 0.0$ & Ms \\
\hline $1414^{\mathrm{d}}$ & 1424 & Hexyl butyrate & $0.1 \pm 0.0$ & Ms \\
\hline $1443^{\mathrm{f}}$ & 1444 & Dimethyl tetradecane & $0.3 \pm 0.0$ & Ms \\
\hline $1468^{d}$ & 1479 & $\delta$-Elemene & $0.3 \pm 0.0$ & Ms \\
\hline $1487^{\mathrm{d}}$ & 1484 & Bicycloelemene & $0.4 \pm 0.1$ & Ms \\
\hline $1488^{c}$ & 1497 & $\alpha$-Copaene & $0.7 \pm 0.1$ & Ms \\
\hline $1496^{\mathrm{d}}$ & 1506 & Decanal & $0.3 \pm 0.1$ & Ms \\
\hline $1523^{c}$ & 1535 & $\beta$-Bourbonene & $0.8 \pm 0.0$ & $\mathrm{t}_{\mathrm{R}}, \mathrm{Ms}$ \\
\hline $1543^{c}$ & 1553 & Linalool & $0.3 \pm 0.0$ & $\mathrm{t}_{\mathrm{R}}, \mathrm{Ms}$ \\
\hline $1554^{\mathrm{d}}$ & 1565 & Linalyl acetate & $1.2 \pm 0.1$ & $\mathrm{t}_{\mathrm{R}}, \mathrm{Ms}$ \\
\hline $1576^{c}$ & 1577 & $\beta$-Ylangene & $0.5 \pm 0.0$ & Ms \\
\hline $1591^{\mathrm{d}}$ & 1600 & $\beta$-Elemene & $0.5 \pm 0.0$ & Ms \\
\hline $1600^{\mathrm{g}}$ & 1600 & Hexadecane & & $\mathrm{t}_{\mathrm{R}}, \mathrm{Ms}$ \\
\hline $1598^{\mathrm{d}}$ & 1612 & $\beta$-Caryophyllene & $32.8 \pm 0.1$ & $\mathrm{t}_{\mathrm{R}}, \mathrm{Ms}$ \\
\hline $1602^{\mathrm{d}}$ & 1617 & Lavandulyl acetate & $0.2 \pm 0.1$ & Ms \\
\hline $1639^{d}$ & 1651 & $\gamma$-Elemene & $1.9 \pm 0.1$ & Ms \\
\hline
\end{tabular}




\begin{tabular}{|c|c|c|c|c|}
\hline $1651^{d}$ & 1668 & (Z)- $\beta$-Farnesene & $2.4 \pm 0.0$ & Ms \\
\hline $1663^{c}$ & 1687 & $\alpha$-Humulene & $8.2 \pm 0.0$ & $\mathrm{t}_{\mathrm{R}}, \mathrm{Ms}$ \\
\hline \multicolumn{5}{|c|}{ Table 1 Continued... } \\
\hline $1700^{f}$ & 1700 & Heptadecane & $0.8 \pm 0.0$ & $\mathrm{t}_{\mathrm{R}}, \mathrm{Ms}$ \\
\hline $1708^{c}$ & 1726 & Germacrene D & $4.9 \pm 0.0$ & Ms \\
\hline $1718^{\mathrm{d}}$ & 1733 & Neryl acetate & $0.2 \pm 0.0$ & Ms \\
\hline $1800^{\mathrm{g}}$ & 1800 & Octadecane & $0.6 \pm 0.1$ & $\mathrm{t}_{\mathrm{R}}, \mathrm{Ms}$ \\
\hline $1935^{\mathrm{d}}$ & 1957 & ( E)- $\beta$-Ionone & $\mathrm{t}$ & Ms \\
\hline $1986^{\mathrm{d}}$ & 2008 & Caryophyllene oxide & $2.3 \pm 0.1$ & $\mathrm{t}_{\mathrm{R}}, \mathrm{Ms}$ \\
\hline $2124^{\mathrm{c}}$ & 2131 & Hexahydrofarnesyl acetone & $1.3 \pm 0.1$ & $\mathrm{t}_{\mathrm{R}}, \mathrm{Ms}$ \\
\hline $2126^{\mathrm{c}}$ & 2144 & Spathulenol & $\mathrm{t}$ & $\mathrm{t}_{\mathrm{R}}, \mathrm{Ms}$ \\
\hline $2164^{\mathrm{d}}$ & 2205 & Thymol & $1.1 \pm 0.1$ & $t_{R}, M s$ \\
\hline $2211^{\mathrm{d}}$ & 2246 & Carvacrol & $\mathrm{t}$ & $\mathrm{t}_{\mathrm{R}}, \mathrm{Ms}$ \\
\hline $2331^{\mathrm{e}}$ & 2316 & 12-Hydroxy- $\beta$-caryophyllene acetate & $6.6 \pm 0.0$ & Ms \\
\hline $2392^{d}$ & 2392 & Caryophyllenol II & $0.5 \pm 0.1$ & Ms \\
\hline $2571^{\mathrm{c}}$ & 2622 & Phytol & $0.7 \pm 0.0$ & Ms \\
\hline $2628^{\mathrm{d}}$ & 2676 & Manool & $0.3 \pm 0.0$ & Ms \\
\hline $2687^{\mathrm{d}}$ & 2696 & Tetradecanoic acid & $0.6 \pm 0.1$ & $\mathrm{t}_{\mathrm{R}}, \mathrm{Ms}$ \\
\hline \multirow[t]{8}{*}{$2913^{\mathrm{d}}$} & 2931 & Hexadecanoic acid & $0.8 \pm 0.3$ & Ms \\
\hline & & Grouped compounds (\%) & & \\
\hline & & Monoterpene hydrocarbones & 24.1 & \\
\hline & & Oxygenated monoterpenes & 3.5 & \\
\hline & & Sesquiterpenes hydrocarbones & 53.4 & \\
\hline & & Oxygenated sesquiterpenes & 2.8 & \\
\hline & & Others & 13.9 & \\
\hline & & Total $\%$ & 97.7 & \\
\hline
\end{tabular}

(c [18]; d [25] ; e [26] ; f [27] ; g [28]) for polar column values; RRI'b RRI Relative retention indices experimentally calculated against $n$-alkanes; *: correct isomer not identified \%: calculated from the FID chromatograms and expressed as mean $\pm \mathrm{SD}(n=3)$; t: Trace $(<0.1 \%)$; ID: Identification Method; Identification method based on the relative retention indices $\left(t_{R}\right)$ of authentic compounds on a HP Innowax column; Ms, identified on the basis of computer matching of the mass spectra with those of the in-house Baser Library of Essential Oil Constituents, Adams, MassFinder and Wiley libraries.

Forty-six compounds constituting about $97.7 \%$ of the essential oil were characterized. The main compounds were characterized as $\beta$-caryophyllene (32.8\%), $\beta$-pinene (9.8\%), $\alpha$-humulene (8.2\%), 12-hydroxy- $\beta$-caryophyllene acetate $(6.6 \%)$, germacrene D $(4.9 \%)$ and $\alpha$-pinene $(4.5 \%)$. The analysis results are given in Table 1. 
However, according to Ozen et al., the main compounds of $S$. montbretii collected from Southeastern Turkey in June 2002 (DUF 9473; Diyarbakır: between Silvan - Batman), were reported thymol (24.0\%) and caryophyllene oxide (26.9\%) [19].

The sesquiterpene hydrocarbon $\beta$-caryophyllene is present in almost all of the Salvia species. $\beta$-caryophyllene; S. aramiensis Rech. f. (7.55\%), S. atropatana Bunge (1.39\%), S.aucheri Bentham var. aucheri (3.02\%), S. bracteata Banks \& Sol. (1.36\%), S. caespitosa Montbret\& Aucher ex Benth. (1.44\%), S. kronenburgii Rech. f. (10.27\%), S. modesta Boiss. (3.78\%), S. multicaulis Vahl (2.09\%), S. pachystachys Trautv (4.83\%), S. pisidica Boiss. \& Heldr. (1.53\%), S. potentillifolia Boiss. Heldr. ex Benth. (1.09\%) S. rosifolia Sm. (1.45\%) and S. sclarea L. (1.05\%) [3].

Salvia montbretii essential oil has high sesquiterpenes hydrocarbones content (53.4\%). To the best of our knowledge, this is the first report on the GC and GC-MS determination of the essential oil composition of $S$. montbretii in this locality. These results provide further support to earlier observations on the existence of distinct chemotypes [3,24] of the same species of Salvia naturally growing the same area.

\section{Disclosure Statement}

No potential conflict of interest was reported by the authors

\section{ORCID}

Fatma Aabak: 0000-0002-9653-1679

Gülsüm Yıldız: 0000-0002-1697-3793

Vagif Atamov: 0000-0002-6718-7979

Mine Kurkcuoglu:0000-0002-9375-0294

\section{References}

[1] I. C. Hedge (1982). Salvia L. In: P.H. (ed.) Flora of Turkey and the East Aegean Islands. Vol.7. Edinburgh Univ. Press, Edinburgh. pp. 400-461.

[2] A. Güner, S. Aslan, T. Ekim, M. Vural, M. T. Babac (2012). List of Turkish Flora (Vascular Plants). Nezahat Gökyigit Botanik Bahcesi ve Flora Arastırmaları Dernegi Yayını. Istanbul, 578.

[3] S. D. Hatipoglu, N. Zorlu, T. Dirmenci, A. C. Goren, T. Ozturk and G. Topcu (2016). Determination of volatile organic compounds in fourty five Salvia Species by thermal desorption-GC-MS technique, Rec. Nat. Prod. 10:6, 659-700.

[4] G. G. Toplan, M. Kurkcuoglu, F. Goger, G. İscan, H. G. Agalar, A. Mat, K. H. C. Baser, M. Koyuncu and G. Sariyar (2017). Composition and biological activities of Salvia veneris Hedge growing in Cyprus, Ind. Crops Prod. 97, 41-48.

[5] T. Aşkun, K. H. C. Başer, G. Tümen and M. Kürkçüoğlu (2010). Characterization of essential oils of some Salvia species and their antimycobacterial activities, Turk. J. Biol. 34, 89-95.

[6] B. Kunduhoglu, M. Kurkcuoglu, M. E. Duru and K. H. C. Baser (2011). Antimicrobial and anticholinesterase activities of the essential oils isolated from Salvia dicroantha Stapf.,Salvia verticillata L. subsp amasiaca (Freyn and Bornm.) Bornm. and Salvia wiedemannii Boiss, J. Med. Plants Res. 5:29, 6484-6490.

[7] I. Kocabas, M. Kaplan, M. Kurkcuoglu and K. H. C. Baser (2010). The effects of different organic manure applications on the essential oil components of Turkish sage (Salvia fruticosa Mill.), Asian J. Chem., 22 (2), 1599-1605.

[8] K. H. C. Baser, B. Demirci, M. Kurkcuoglu, F. Satil, G. Tumen (2009). Comparative morphological and phytochemical characterization of Salvia cadmica Boiss. And S. smyrnaea Boiss., Pakistan J. Bot., 41:4, 1545-1555.

[9] M. Koşar, Z. Tunalıer, T. Özek, M. Kürkçüoğlu ve K. H. C. Başer (2005). A simple method to obtain essential oils from Salvia triloba L. and Laurus nobilis L. by using microwave-assisted hydrodistillation, Z. Naturforsch. C.,60c, 501-504.

[10] M. Kürkçüoğlu, B. Demirci, K. H. C. Başer, T. Dirmenci, G. Tumen ve U. Ozgen (2005).The essential oil of Salvia limbata C.A.Meyer growing in Turkey, J.Essent. Oil Res.,17:2, 192-193.

[11] M. Kürkçüoğlu, K. H. C. Başer ve H. Duman (2002). Composition of essential oils from two varieties of Salvia aucheri Bentham growing in Turkey, J.Essent. Oil Res.,14, 241-242. 
[12] G. Tümen, K. H. C. Başer, M. Kürkçüoğlu ve H. Duman (1998). Composition of the essential oil of Salvia cedronella Boiss. from Turkey, J.Essent. Oil Res.,10, 713-715.

[13] K. H. C. Başer, M. Kürkçüoğlu ve Z. Aytaç (1998). Composition of the essential oil of Salvia euphratica Monbretet Aucherex Bentham var. euphratica from Turkey, Flav. Fragr.J.,13, 63-64.

[14] S. K. Jash, D. Gorai and R. Roy (2016). Salvia genus and triterpenoids, IJPSR,7(12), 4710-4732.

[15] A. Ulubelen, G. Topcu, H. Lotter, H. Wagner and C. Eris (1994). Triterpenoids from the aerial parts of Salvia montbretii, Phytochemistry, 36, $413-415$.

[16] G. Topcu and A. Ulubelen (1996). Abietane and rearranged abietane diterpenes from Salvia montbretii, J. Nat. Prod.,59, 734-737.

[17] A. Ulubelen and G. Topcu (1992). New abietane diterpenoids from Salvia montbretii, J. Nat. Prod., 55:4, 441-444.

[18] A. Kaya, M. Dinc, S. Dogu and B. Demirci (2017). Compositions of essential oils of Salvia adenophylla, Salvia pilifera, and Salvia viscosa in Turkey, J. Essent. Oil Res., 29: 3, 233-239.

[19] H. C. Ozen, Z. Toker and A. S. Ertekin (2004). Essential oil composition of two Salvia species from Turkey, Adv. Food Sci., 26:1, 32-34.

[20] R. P. Adams (2007). Identification of Essential Oil Components by Gas Chromatography/Mass Spectrometry, Allured Publ. Corp, Carol Stream, IL.

[21] D. H. Hochmuth (2008). MassFinder-4, Hochmuth Scientific Consulting, Hamburg, Germany.

[22] F. W. McLafferty, D. B. Stauffer (1989). The Wiley/NBS Registry of Mass Spectral Data, J.Wiley and Sons: New York.

[23] J. Curvers, J. Rijks, C. Cramers, K. Knauss and P. Larson (1985). Temperature pro-grammed retention indexes: calculation from isothermal data. Part 1: Theory, J. High Res. Chromatog., 8, 607-610.

[24] K.H.C. Baser (2002). Aromatic biodiversity among the flowering plant taxa of Turkey, Pure Appl. Chem. 74, 527-545.

[25] V.I. Babushok, P.J. Linstrom and I.G. Zenkevich (2011). Retention indices for frequently reported compounds of plant essential oils, J. Phys. Chem. Ref. Data, 40.

[26] N. Tabanca, B. Demirci, T. Ozek, N. Kirimer, K.H.C. Baser, E. Bedir, I.A. Khan and D.E. Wedge (2006). Gas chromatographic-mass spectrometric analysis of essential oils from Pimpinella species gathered from Central and Northern Turkey, J. Chromatogr. A. 1117, 194-205.

[27] B. Demirci, M. Toyota, F. Demirci, M.Y. Dadandi and K.H.C. Baser (2009). Anticandidal pimaradiene diterpene from Phlomis essential oils, C. R. Chimie 12, 612-621.

[28] S. Alan, M. Kürkçüoğlu and K.H.C. Baser (2011). The composition of the essential oils of Calamintha pamphylica subspecies, Turk J. Biol. 35, 259-265.

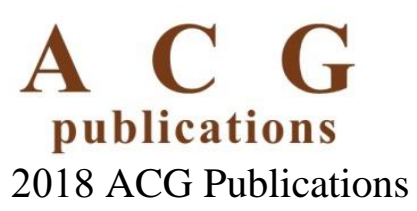

